\title{
PHOTOINDUCED ELECTRON ACCUMULATION OF TITANIUM DIOXIDE NANOPARTICLES MODIFIED ELECTRODES
}

\author{
HIROKAZU MIYOSHI \\ Radioisotope Research Center, The University of Tokushima, 3-18-15 Kuromoto-cho, Tokushima 770-8503, \\ Japan \\ hmiyoshi@ri.tokushima-u.ac.jp \\ KENSHO SAKAMOTO, MASARU KURASHINA and EIJI KANEZAKI* \\ Department of Chemical Science and Technology, Faculty of Engineering, The University of Tokushima, 2-1 \\ Minami Josanjima-cho, Tokushima 770-8506, Japan \\ "kanezaki@chem.tokushima-u.ac.jp
}

\begin{abstract}
Titanium dioxide $\left(\mathrm{TiO}_{2}\right)$ nanoparticles $(\mathrm{Nps})$ were prepared by the hydrolysis of titanium tetraisopropoxide (TTIP) in 2-propanol with different water contents $(0.5 \mathrm{vol} \%$ to $7.2 \mathrm{vol} \%)$ at 45 ${ }^{\circ} \mathrm{C}$. The diameter of the Nps was estimated to be $1.5 \pm 0.5 \mathrm{~nm}\left(\mathrm{~L}-\mathrm{TiO}_{2}\right)$ and $3.0 \pm 0.6 \mathrm{~nm}\left(\mathrm{~S}-\mathrm{TiO}_{2}\right)$ from the onset wavelength in the absorption spectra and by transmission electron microscopy (TEM). A modified Pt electrode with a three-layered sandwich structure was prepared; the outermost and innermost layers were composed of $\mathrm{S}-\mathrm{TiO}_{2}$ and $\mathrm{L}-\mathrm{TiO}_{2}$, respectively, and the middle layer contained 1, 1'-dimethyl-4,4'-bipyridyl $\left(\mathrm{MV}^{2+}\right) / \mathrm{Nafion}{ }^{\circledR}$. Irradiation by a $500 \mathrm{~W}$ superhigh-pressure mercury lamp produced electrons in the conduction band of $\mathrm{TiO}_{2}$. An anodic current was observed after turning off the light. The mechanism by which anodic current is generated after turning off the radiation involves the reduction of $\mathrm{MV}^{2+}$ to $\mathrm{MV}^{+\cdot}$ by photogenerated electrons on the Nps and the diffusion of $\mathrm{MV}^{+}$in the middle layer. After turning off the irradiation, $\mathrm{MV}^{+\bullet}$ transferred an electron to the Pt electrode via holes in the innermost layer or the conduction band of $\mathrm{S}^{-\mathrm{TiO}_{2}}$ coincidentally localized on the Pt electrode, resulting in the generation of the anodic current. The generation of $\mathrm{MV}^{+\bullet}$ was confirmed by the absorption spectra of $\mathrm{MV}^{+\bullet}$. As a sacrificial reagent, 2-propanol $(0.1 \mathrm{M})$ was used.
\end{abstract}

Keywords: $\mathrm{TiO}_{2}$ nanoparticle; electron accumulation; methylviologen

\section{Introduction}

Titanium dioxide $\left(\mathrm{TiO}_{2}\right)$ nanoparticles $(\mathrm{Nps})$ are a well-known photocatalyst ${ }^{1}$ and have been used in dye-sensitized solar cells ${ }^{2}$. Generally, $\mathrm{TiO}_{2} \mathrm{Nps}$ of various sizes can be prepared by a sol-gel method while controlling the titanium tetraisopropoxide (TTIP) content, reaction time, and temperature ${ }^{3}$. The size of $\mathrm{TiO}_{2} \mathrm{Nps}$ is related to their band gap energy ${ }^{4}$. A simple preparation of $\mathrm{TiO}_{2} \mathrm{Nps}$ with a capsule structure has also been reported ${ }^{5}$. Miyoshi et al. reported that photogenerated electrons that had accumulated on encapsulated 1,1'-dimethyl-4,4'-bipyridyl $\left(\mathrm{MV}^{2+}\right)$ molecules in $\mathrm{TiO}_{2}$ nanocapsules were detected as $\mathrm{MV}^{+\bullet}$ radicals and that their electrons were released as an anodic current after turning off the light used for photogeneration ${ }^{6}$. However, in the preparation of the nanocapsules, $\mathrm{Au} \mathrm{Nps}$ were used as a core. However, $\mathrm{Au} \mathrm{Nps}$ are expensive and poisonous $\mathrm{NaCN}$ was used to dissolve the $\mathrm{Au} \mathrm{Nps}$ to form the nanocapsules. For this 
reason, a layered structure, which was composed of a Nafion ${ }^{\circledR}$ layer containing $\mathrm{MV}^{2+}$ and layers of $\mathrm{TiO}_{2} \mathrm{Nps}$ with different sizes, was used in this study instead of the capsule structure. The deposition of $\mathrm{MV}^{2+}$ in Nafion ${ }^{\circledR}$ films on $\mathrm{SnO}_{2}$ electrodes and their electrochemical properties have also been reported ${ }^{7}$. The advantages of the layered structure are twofold. One is the control of the diffusion distance for $\mathrm{MV}^{2+}$, which depends on the thickness of the Nafion ${ }^{\circledR}$ layer, and the other is the ability to control the potentials at the conduction band edges by changing the size of the $\mathrm{TiO}_{2} \mathrm{Nps}$ in contact with the Nafion ${ }^{\circledR}$ layer. These advantages will make it possible to prepare a simple electron capacitor to accumulate photogenerated electrons and to release them as an anodic current in the dark. Such a system will increase the likelihood of $\mathrm{TiO}_{2} \mathrm{Nps}$ in a dye-sensitized solar cell acting as a photocapacitor. Recently, Wang et al. have reported a water-assisted synthesis method for anatase $\mathrm{TiO}_{2}$ nanocrystals ${ }^{8}$.

In this study, $\mathrm{TiO}_{2} \mathrm{Nps}$ of two different sizes were simply prepared by changing the water content during synthesis, and their sizes were estimated from their absorption spectra and by transmission electron microscopy (TEM). Electrodes modified by the $\mathrm{TiO}_{2} \mathrm{Nps}$ indicated that a photoanodic current was generated and that electrons accumulated in $\mathrm{MV}^{2+}$ simultaneously. The accumulation of electrons on the $\mathrm{TiO}_{2} \mathrm{Nps}-$ $\mathrm{MV}^{2+} / \mathrm{Nafion}{ }^{\circledR}$ modified electrode was investigated by observing the anodic current after turning off the light used for photogeneration. The mechanisms of the electron accumulation and release are discussed.

\section{Experimental}

\subsection{Chemicals}

TTIP and Nafion ${ }^{\circledR} 117$ (5 $\mathrm{wt} \%$ Nafion in alcoholic solution) were purchased from Aldrich Co., Ltd. 2-propanol, $\mathrm{MV}^{2+}$, potassium chloride, and sodium sulfate were purchased from Wako Pure Chemicals Co., Ltd., and were used without further purification.

\subsection{Preparation of $\mathrm{TiO}_{2} \mathrm{Nps}$}

TTIP $(20 \mu \mathrm{l})$ was mixed in $10 \mathrm{ml}$ of 2-propanol, and the solution was heated at $45{ }^{\circ} \mathrm{C}$ using a hot stirrer, after which $49 \mu 1,74 \mu 1,148 \mu 1,360 \mu 1$, or $720 \mu 1$ of distilled water was poured into the solution. Then, the solution was stirred for $30 \mathrm{~min}$ using a stirrer. To remove unreacted reagents, ultrafiltration equipment (Millipore Stirred Ultrafiltration Cell) with a membrane filter (Millipore YM-100) was used. Next, the solution was

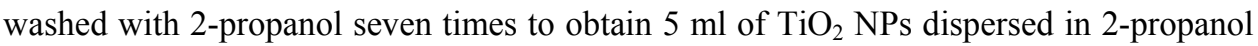
solution. $\mathrm{L}_{-}-\mathrm{TiO}_{2}$ and $\mathrm{S}-\mathrm{TiO}_{2}$ refer to the Nps obtained with the addition of $74 \mu \mathrm{l}$ and $720 \mu \mathrm{l}$ distilled water, respectively. Their absorption spectra were measured using a UVvis spectrometer (Shimadzu, UV-1700). TEM (Hitachi, H-800) observation was performed for $\mathrm{L}-\mathrm{TiO}_{2}$ and $\mathrm{S}-\mathrm{TiO}_{2}$ after their solutions were added dropwise onto a copper grid and then dried.

\subsection{Photoelectrochemical experiments}

A typical $\mathrm{TiO}_{2} \mathrm{Nps}-\mathrm{MV}^{2+} / \mathrm{Nafion}{ }^{\circledR}$ modified electrode was prepared as follows. Three 
hundred microliters of $\mathrm{L}_{-} \mathrm{TiO}_{2}$ was coated on a 1.5 -cm-diameter Pt plate and then dried. Then, $200 \mu \mathrm{l}$ of $\mathrm{MV}^{2+}(0.138 \mathrm{M}) / 0.5 \operatorname{vol} \% \mathrm{Nafion}{ }^{\circledR}$ alcohol solution, which had been diluted tenfold by water (1:1), was added dropwise and dried. After that, $300 \mu 1$ of S$\mathrm{TiO}_{2}$ was added and dried. Finally, $200 \mu \mathrm{l}$ of $0.5 \mathrm{vol} \% \mathrm{Nafion}{ }^{\circledR}$ alcohol solution, which had been diluted tenfold by water, was coated on the top. A $\mathrm{TiO}_{2} \mathrm{Nps}-\mathrm{Nafion}{ }^{\circledR}$ modified electrode that contained no $\mathrm{MV}^{2+}$ was also prepared. Photoelectrochemical experiments were performed using a $500 \mathrm{~W}$ superhigh-pressure mercury lamp (Ushio, UI-501C) and a potentiostat (ALS/DY2323 Bi-Potentiostat). The irradiated area on the electrode was 0.63 $\mathrm{cm}^{2}$ and a water filter was used to remove wavelengths of less than $300 \mathrm{~nm}$.

FE-SEM (Hitachi, S-4700) observation of a cross section of the $\mathrm{TiO}_{2} \mathrm{Nps}-$ $\mathrm{MV}^{2+} / \mathrm{Nafion}{ }^{\circledR}$ modified electrode was performed by preparing a $\mathrm{TiO}_{2} \mathrm{Nps}-$ $\mathrm{MV}^{2+} / \mathrm{Nafion}{ }^{\circledR}$ modified rectangular glass plate $\left(1 \mathrm{~cm}^{2}\right)$ by the same procedure as above.

\section{Results and Discussion}

Figure 1 shows absorption spectra of $\mathrm{TiO}_{2} \mathrm{Nps}$ prepared by the addition of different water contents $(49 \mu \mathrm{l}, 74 \mu \mathrm{l}, 148 \mu \mathrm{l}, 360 \mu \mathrm{l}$, and $720 \mu \mathrm{l})$. The onset wavelength underwent a redshift with increasing water content.

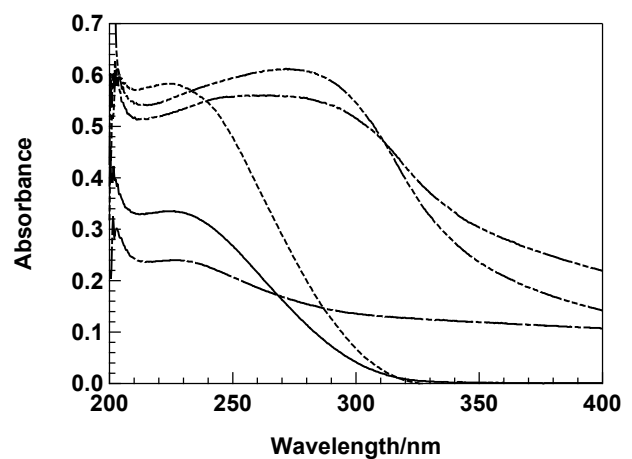

Fig. 1. Absorption spectra of $\mathrm{TiO}_{2} \mathrm{Nps}$ dispersed in 2-propanol. Water contents: $49 \mu \mathrm{l}(-), 74 \mu \mathrm{l}(--\mathrm{-}), 148$

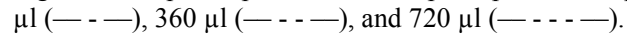

The onset wavelength of each $\mathrm{TiO}_{2} \mathrm{~Np}$ is related to the band gap energy ${ }^{1,4}$, and the particle size can be estimated from its relationship with the band gap energy 9 .

Table 1. Onset wavelength, band gap energy, and particle size for different water contents.

\begin{tabular}{cccc}
$\begin{array}{c}\text { Water content } \\
/ \mu 1\end{array}$ & $\begin{array}{c}\text { Onset wavelength } \\
\text { /nm }\end{array}$ & $\begin{array}{c}\text { Band gap energy } \\
\text { /eV }\end{array}$ & $\begin{array}{c}\text { Particle size } \\
\text { /nm }\end{array}$ \\
\hline 49 & 303 & 4.09 & 0.94 \\
74 & 304 & 4.08 & 0.94 \\
148 & 349 & 3.55 & 1.4 \\
360 & 395 & 3.14 & 3.4 \\
720 & 380 & 3.26 & 2.2 \\
\hline
\end{tabular}

Table 1 shows the onset wavelength, band gap energy, and particle size for different water contents. The results in Table 1 indicate that the particle size and band gap depended on the water content during the preparation. The band gap energy increased 
and the particle size decreased with decreasing water content except for the case of 720 $\mu \mathrm{l}$ of water. $\mathrm{L}_{-}-\mathrm{TiO}_{2}$, with $74 \mu \mathrm{l}$ of water, and $\mathrm{S}-\mathrm{TiO}_{2}$, with $720 \mu \mathrm{l}$ of water, were used in the photoelectrochemical experiments. The $\mathrm{L}_{-} \mathrm{TiO}_{2} \mathrm{Nps}$ had a size of $1.5 \pm 0.5 \mathrm{~nm}$ and the potential at the conduction band edge was estimated to be $-0.643 \mathrm{~V}^{\mathrm{vs} \mathrm{SCE}} \mathrm{S}^{9}$ at $\mathrm{pH}$ 6.3. The $\mathrm{S}-\mathrm{TiO}_{2} \mathrm{Nps}$ had a size of $3.0 \pm 0.6 \mathrm{~nm}$ and the potential at the conduction band edge was estimated to be $-0.706 \mathrm{~V}_{\mathrm{vs}} \mathrm{SCE}^{9}$ at $\mathrm{pH}$ 6.3. The redox potential $(-0.64 \mathrm{~V}$ vs $\mathrm{SCE})$ of $\mathrm{MV}^{2+} / \mathrm{MV}^{+\cdot}$ was equal to or lower than the potentials of the conduction band edges of $\mathrm{S}-\mathrm{TiO}_{2}$ and $\mathrm{L}-\mathrm{TiO}_{2}$, respectively. Therefore, electron accumulation will occur when using $\mathrm{MV}^{2+}$ in a $\mathrm{Nafion}{ }^{\circledR}$ layer as a capacitor.

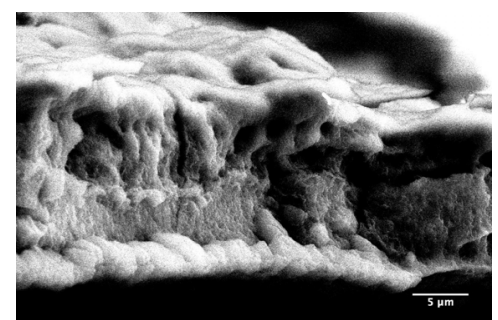

Fig. 2. FE-SEM cross-section image of $\mathrm{S}-\mathrm{TiO}_{2}-\mathrm{MV}^{2+} / \mathrm{Nafion} \AA-\mathrm{L}-\mathrm{TiO}_{2}$

Then an $\mathrm{S}_{-} \mathrm{TiO}_{2}-\mathrm{MV}^{2+} / \mathrm{Nafion}{ }^{\circledR}-\mathrm{L}-\mathrm{TiO}_{2}$ modified electrode was fabricated by coating a Pt plate with $\mathrm{L}_{-} \mathrm{TiO}_{2}$, then with $\mathrm{MV}^{2+} / \mathrm{Nafion}{ }^{\circledR}$, and finally with $\mathrm{S}-\mathrm{TiO}_{2}$, as shown in Figure 2. Both $\mathrm{L}-\mathrm{TiO}_{2}$ and $\mathrm{S}-\mathrm{TiO}_{2}$ donate photogenerated electrons to $\mathrm{MV}^{2+}$. $\mathrm{L}_{-}-\mathrm{TiO}_{2}$ was used to prevent the direct flow of electrons from $\mathrm{MV}^{+\bullet}$ to the Pt electrode owing to the higher potential at the conduction band edge. Part of the $\mathrm{S}-\mathrm{TiO}_{2}$ may be localized on the Pt plate electrode. This $\mathrm{S}_{-} \mathrm{TiO}_{2}$ on the Pt plate electrode accepted electrons from $\mathrm{MV}^{+\bullet}$, which flowed to the Pt plate electrode. This modified electrode demonstrates a model of photocharging, that is, upon photocharge separation on the $\mathrm{TiO}_{2} \mathrm{Nps}$, electrons are stored in $\mathrm{MV}^{2+}$ and $\mathrm{MV}^{+\bullet}$, then, after the light used for photocharging is turned off, the stored electrons are released. In this case, some of the $\mathrm{S}-\mathrm{TiO}_{2}$ attached to the $\mathrm{Pt}$ electrode directly, and during light irradiation electrons localized on the particles, giving them a negative charge and preventing electron transfer from $\mathrm{MV}^{+\bullet}$.

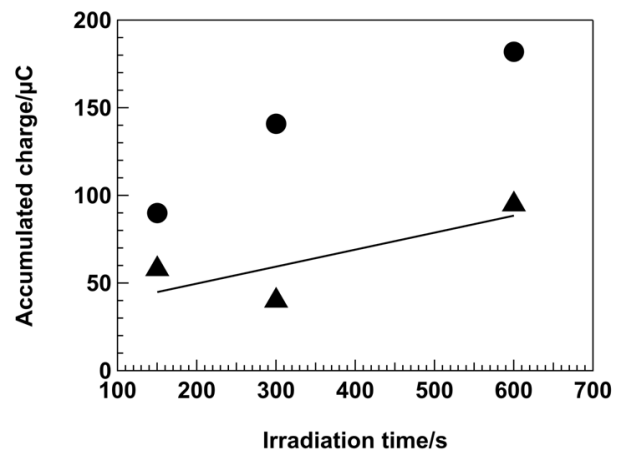

Fig. 3. Plot of accumulated charge for $\mathrm{TiO}_{2} \mathrm{Nps}-\mathrm{MV}^{2+} / \mathrm{Nafion} \AA(\boldsymbol{O})$ and $\mathrm{TiO}_{2} \mathrm{NPs}-\mathrm{Nafion} \AA(\boldsymbol{\Delta})$ modified electrode vs irradiation time.

The validity of this model was investigated using the modified electrode by measuring the photocharge and discharge. 
Figure 3 shows that the accumulated charge of the $\mathrm{S}-\mathrm{TiO}_{2}-\mathrm{MV}^{2+} / \mathrm{Nafion}{ }^{\circledR}-\mathrm{L}-\mathrm{TiO}_{2}$ modified electrode depends on the irradiation time. That is, the photogenerated electrons that were transferred to $\mathrm{MV}^{2+}$ and $\mathrm{MV}^{+\bullet}$ in the middle layer accumulated. Then, after the light was turned off, the electrons of $\mathrm{MV}^{+\bullet}$ transferred via $\mathrm{S}-\mathrm{TiO}_{2}$ to the Pt electrode. This led to the accumulation of charge due to the formation of an anodic current. The observed accumulated charge for $\mathrm{S}-\mathrm{TiO}_{2}-\mathrm{Nafion}{ }^{\circledR}-\mathrm{L}-\mathrm{TiO}_{2}$ increased from $58 \mu \mathrm{C}$ after $150 \mathrm{~s}$ irradiation to $95 \mu \mathrm{C}$ after $600 \mathrm{~s}$ irradiation. However, the accumulated charge did not increase linearly, because dissolved $\mathrm{O}_{2}$ could react easily with the $\mathrm{MV}^{+\bullet}$. The observed long retention time for the anode current after turning off the light may be due to the diffusion of $\mathrm{MV}^{+\cdot}$ in the Nafion ${ }^{\circledR}$ layer. That is, $\mathrm{MV}^{2+}$ diffuses in the layer, and when it becomes attached on the photoirradiated $\mathrm{L}^{-\mathrm{TiO}_{2}}$, it accepts an electron and diffuses. Then, $\mathrm{MV}^{+\bullet}$ becomes attached to $\mathrm{S}-\mathrm{TiO}_{2}$ and the electron is transferred to $\mathrm{S}$ $\mathrm{TiO}_{2}$ and the $\mathrm{Pt}$ electrode. However, in the presence of $\mathrm{O}_{2}$, the stored electron in $\mathrm{MV}^{+}$ will transfer to $\mathrm{O}_{2}$ and disappear. The absorption spectra of $\mathrm{MV}^{+\bullet}$ after light irradiation are shown in Figure 4, which indicates that $\mathrm{MV}^{+\bullet}$ was produced in this $\mathrm{S}_{-} \mathrm{TiO}_{2}$ $\mathrm{MV}^{2+} / \mathrm{Nafion}{ }^{\circledR}-\mathrm{L}-\mathrm{TiO}_{2}$ system. The lifetime of $\mathrm{MV}^{+\cdot}$ corresponding to a $10 \%$ decrease in absorbance was $54 \mathrm{~s}$, compared with 29.4 min for $\mathrm{TiO}_{2}$ nanocapsules ${ }^{6}$, indicating that the Nafion ${ }^{\circledR}$ layer was not protected from $\mathrm{O}_{2}$ in the solution and that $\mathrm{O}_{2}$ rapidly reacted with $\mathrm{MV}^{+}$.

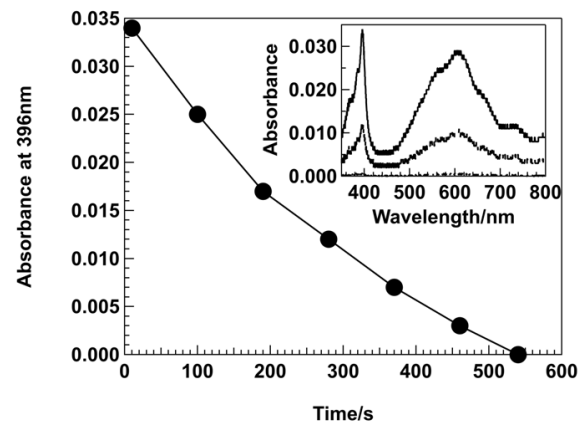

Fig. 4. Plot of absorbance of $\mathrm{MV}^{+\bullet}$ at $396 \mathrm{~nm}$ for $\mathrm{TiO}_{2} \mathrm{Nps}-\mathrm{MV}^{2+} / \mathrm{Nafion} \circledast$ coated on glass plate in an aqueous solution under air. Light irradiation: $500 \mathrm{~W}$ superhigh-pressure mercury lamp. Inset: Absorption spectra of $\mathrm{MV}^{+\cdot}$ at $280 \mathrm{~s}(--)^{-}$, and $540 \mathrm{~s}\left(---{ }_{-}\right)$.

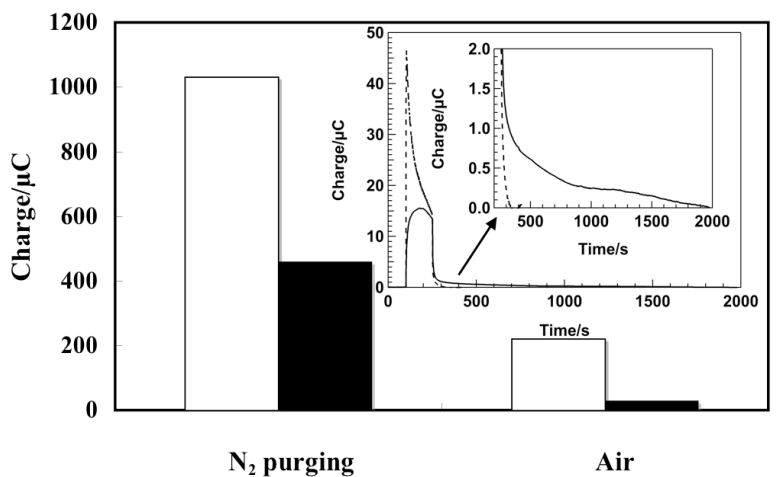

Fig. 5. Plot of charges stored in $\mathrm{MV}^{2+}$ (white) and charges released from $\mathrm{MV}^{+\bullet}$ (black) for $\mathrm{TiO}_{2} \mathrm{Nps}^{-\mathrm{MV}^{2+}}$ $/ \mathrm{Nafion}{ }^{\circledR}$ under $\mathrm{N}_{2}$ purging and air. Inset: charge-time curves during light irradiation and after turning off the light for $\mathrm{TiO}_{2} \mathrm{Nps}-\mathrm{MV}^{2+} / \mathrm{Nafion}{ }^{\circledR}(-)$ ) and $\mathrm{TiO}_{2} \mathrm{Nps} / \mathrm{Nafion}{ }^{\circledR}(------)$. 
The evaluation of the accumulated charge in this system was also performed in the presence of a sacrificial reagent without $\mathrm{O}_{2}$. Figure 5 shows a plot of charges stored in $\mathrm{MV}^{2+}$ and charges released from $\mathrm{MV}^{+\bullet}$ for $\mathrm{TiO}_{2} \mathrm{Nps}-\mathrm{MV}^{2+} / \mathrm{Nafion}{ }^{\circledR}$ under $\mathrm{N}_{2}$ purging and air. $\mathrm{N}_{2}$ purging and the sacrificial reagent resulted in increases in charge accumulation and the observed retention time for $\mathrm{S}-\mathrm{TiO}_{2}-\mathrm{MV}^{2+}-\mathrm{L}-\mathrm{TiO}_{2}$ but not for $\mathrm{S}$ $\mathrm{TiO}_{2}-\mathrm{L}-\mathrm{TiO}_{2}$ as shown in the inset figures, indicating that $\mathrm{MV}^{2+}$ acted as a capacitor for the electrons. That is, $\mathrm{N}_{2}$ purging led to the prevention of quenching of $\mathrm{MV}^{+\bullet}$ by $\mathrm{O}_{2}$. The efficiency of the use of the charges stored in $\mathrm{MV}^{2+}$ after turning off the light increased from $14 \%$ under air to $45 \%$ under $\mathrm{N}_{2}$ purging, as shown in Figure 5, and the loss of charge may have been due to the decomposition of $\mathrm{MV}^{+\bullet}$. Finally, the observed retention time of the anodic current after turning off the light also increased from $470 \pm 200 \mathrm{~s}$ under air to $1340 \pm 420 \mathrm{~s}$ under $\mathrm{N}_{2}$ purging as shown in the inset figures.

\section{Conclusion}

$\mathrm{L}-\mathrm{TiO}_{2}$ and $\mathrm{S}-\mathrm{TiO}_{2}$ were selected on the basis of their potential at the conduction band edge compared with the redox potential of $\mathrm{MV}^{2+}$, where the $\mathrm{L}_{-} \mathrm{TiO}_{2} \mathrm{Nps}$ had a size of $1.5 \pm 0.5 \mathrm{~nm}$ and the potential at the conduction band edge was estimated to be $-0.643 \mathrm{~V}$ vs $\mathrm{SCE}$ at $\mathrm{pH}$ 6.3, whereas the $\mathrm{S}-\mathrm{TiO}_{2} \mathrm{Nps}$ had a size of $3.0 \pm 0.6 \mathrm{~nm}$ and the potential at the conduction band edge was estimated to be $-0.706 \mathrm{~V}$ vs SCE at $\mathrm{pH} 6.3$. Electrodes modified by $\mathrm{TiO}_{2}$ Nps with an $\mathrm{MV}^{2+} / \mathrm{Nafion}{ }^{\circledR}$ interlayer were prepared. The photogenerated electrons transferred to $\mathrm{MV}^{2+}$, and after turning off the light used for photogeneration an anodic current was observed. The accumulated charge depended on the irradiation time, the presence of $\mathrm{O}_{2}$, and the use of a sacrificial reagent. The efficiency of the use of the charges stored in $\mathrm{MV}^{2+}$ after turning off the light increased from $14 \%$ under air to $45 \%$ under $\mathrm{N}_{2}$ purging. The observed retention time of the anodic current after turning off the light increased from $470 \pm 200 \mathrm{~s}$ under air to $1340 \pm 420 \mathrm{~s}$ under $\mathrm{N}_{2}$ purging. The proposed system acts as a simple capacitor that accumulates photogenerated electrons on the modified electrode itself.

\section{Acknowledgments}

We greatly appreciate Mr. Tomoyuki Ueki at Graduate School, Institute of Socio-Techno Science, for help in FE-SEM and TEM observations.

\section{References}

1. B. Ohtani, J. Photochem. Photobiol. C, 11, 157 (2010).

2. M. Gratzel, Acc. Chem. Res., 42, 1788 (2009).

3. X.-Q. Chen, W.-H. Shen and H.-B. Liu, Chem. Eng. Technol., 31, 1730 (2008).

4. S. Kaniyankandy and H. N. Ghosh, J. Mater. Chem., 19, 3523 (2009).

5. H. G. Yang and H. C. Zeng, J. Phys. Chem. B, 108, 3492 (2006).

6. H. Miyoshi, S. Katayama, M. Kurashina and E. Kanezaki, Chem. Commun., 46, 3797 (2010).

7. O. Johansen, J. W. Loder, A. W.-H. Mau, J. Rabani and W. H. F. Sasse, Langmuir, 8, 2577 (1992).

8. P. Wang, T. Xie, L. Peng, H. Li, T. Wu, S. Pang and D. Wang, J. Phys. Chem. C, 112, 6648 (2008).

9. H. Miyoshi, S. Nippa, H. Uchida, H. Mori and H. Yoneyama, Bull. Chem. Soc. Jpn., 63, 3380 (1990). 